\title{
Effect of dietary L-tryptophan on cannibalism, growth and survival of Asian seabass, Lates calcarifer (Bloch, 1790) fry
}

\author{
PREM KUMAR*, M. KAILASAM, S. N. SETHI, K. SUKUMARAN, G. BISWAS, \\ R. SUBBURAJ, G. THIAGARAJAN, T. K. GHOSHAL AND K. K. VIJAYAN \\ ${ }^{*}$ Kakdwip Research Centre of ICAR-Central Institute of Brackishwater Aquaculture, South 24 Parganas \\ Kakdwip - 743 347, West Bengal, India \\ ICAR-Central Institute of Brackishwater Aquaculture, 75, Santhome High Road, R. A. Puram Chennai- 600028 \\ Tamil Nadu, India \\ e-mail: prem.cife@gmail.com
}

\begin{abstract}
The effect of L-tryptophan (TRP) supplemented diets at levels of $0,0.5,1.0,1.5$ and $2 \%$ on cannibalism, survival and growth performance of Asian seabass, Lates calcarifer (Bloch, 1790) fry was evaluated. Thirty days old seabass fry (mean weight: $0.31 \pm 0.16 \mathrm{~g}$ ) were reared for 45 days in a recirculating aquaculture system. Results of the present experiment showed that L-tryptophan (TRP) supplementation from 0.5 to $2 \%$ in diet significantly $(\mathrm{p}<0.05)$ reduced cannibalism compared to control diet and did not affect growth performance. The lowest survival percentage (14\%) was noticed in control group, whereas a higher survival percentage (33.33 to 39.80) was observed in TRP supplemented groups. Coefficient of size variation (\%) ranged from 21.50 to 91.61 and decreased with increased level of TRP supplementation, Similar results were also obtained in size heterogeneity. Based on the results of the study, it is recommended to supplement $0.5 \%$ of TRP in larval diet to reduce cannibalism and improve survival of seabass fry.
\end{abstract}

Keywords: Cannibalism, Growth, L-tryptophan, Seabass, Survival

\section{Introduction}

Asian seabass, Lates calcarifer (Bloch, 1790) commonly known as bhetki or barramundi is an economically important carnivorous food fish of tropical and subtropical areas (Greenwood, 1976). Seabass is a euryhaline (Lim et al., 1986) protandric hermaphrodite (Grey, 1987) and is cannibalistic in nature. The potential for $L$. calcarifer farming has increased in India after the successful induced breeding of this fish at the ICAR-Central Institute of Brackishwater Aquaculture (ICAR-CIBA), Chennai, India (Thirunavukkarasu et al., 2001). In predatory fish larval rearing, intra-cohort cannibalism has a major impact on survival (Loadman et al., 1986; Katavic et al., 1989; Baras, 1999; 2013). During the early life stages, size heterogeneity is more and type I cannibalism (partial and tail-first ingestion) is prominent (Cuff, 1980; Baras and Jobling, 2002; Baras, 2013). Later, as size heterogeneity increases, type II cannibalism dominates, which is characterised by total prey ingestion (Cuff, 1980; Hecht and Appelbaum, 1988; Hecht and Pienaar 1993; Baras, 1999; Baras et al., 2003). In European seabass, Dicentrachus labrax, 37\% fish were found to be cannibalistic accounting to $66 \%$ loss in six weeks (Katavic et al., 1989). Consequences of size variation during larval stage are more severe due to larger mouth to body size ratio, which allows cannibalism on prey that is even slightly smaller (Baras, 1998). Baras and Jobling (2002) reported several population and external factors (environmental structure, temperature, light intensity, food availability and food quality) that regulate size heterogeneity and cannibalism in fishes. Cannibalism during larviculture of seabass is controlled by routine size grading, frequent feeding and gradual weaning from live food to formulated diets. Grading is a labour intensive activity which also causes additional mortality of fry. An alternative strategy could be the use of dietary factors that reduce cannibalistic behaviour. Tryptophan (TRP), which is a precursor of serotonin (5-HT), is an essential amino acid, widely used in controlling aggression in vertebrates, including fishes. Increased TRP content in the feed enhances fish brain serotonergic activity with stress-releasing effects (Johnston et al., 1990; de Pedro et al., 1998; Winberg et al., 2001; Lepage et al., 2002) or decreased aggression (Winberg et al., 2001; Hseu et al., 2003; Hoglund et al., 2005). Based on the above factors, we assumed that dietary TRP may suppress cannibalism in L. calcarifer fry by increasing brain serotonergic activity. It is also reported that high levels of brain serotonin reduces the food intake in fish (De Pedro et al., 1998; 
Hseu et al., 2003; Papoutsoglou et al., 2005a). Therefore, it is important to find the growth performance of fish fed with TRP supplemented diets. The present experiment was conducted to optimise the TRP supplementation that would reduce cannibalism in Asian seabass fry without affecting growth performance.

\section{Materials and methods}

The experiment was conducted with 30 day old seabass fry (mean length: $1.5 \mathrm{~cm}$ and mean weight: $0.054 \mathrm{~g}$ ) produced from the Asian seabass hatchery, ICAR-Central Institute of Brackishwater Aquaculture (ICAR-CIBA), Chennai. The fry were completely weaned to a commercial larval diet. Commercial fish larval diets (500 and $800 \mu \mathrm{m}$ dia, $55 \%$ protein and $10 \%$ lipid) were used for preparing the experimental feed. Supplemented diets containing 0\% (T1), $0.5 \%$ (T2), 1\% (T3), 1.5\% (T4) and 2\% TRP (T5) was prepared by the sprinkle method (Jarosław Kro'l and Zdzisław Zake, 2015). The TRP (crystalline L-tryptophan, Himedia) for each treatment was weighed, dissolved in hot water plus ethanol $(80 \%)$ and then sprinkled on the commercial diet. The diets were dried in oven at $37^{\circ} \mathrm{C}$ for $1 \mathrm{~h}$ and then cooled and stored at $4^{\circ} \mathrm{C}$ until use. To evade the palatability effect, control (T1) diet was also spread with the same ethanol water solution. Thirty days old fry were randomly distributed into five groups and fed on experimental diets viz., T1, T2, T3, T4 and T5. Each diet had three replicates. The fish were reared for 45 days in a recirculating aquaculture system (RAS) consisting of 15 FRP tanks of 2501 capacity (water volume 200 l). Each tank was stocked with 400 fry @ 2 fry $1^{-1}$. The water flowthrough in the rearing tanks was maintained approximately at $51 \mathrm{~min}^{-1}$. Water temperature, salinity, $\mathrm{pH}$ and dissolved oxygen were measured daily while total ammonia and nitrite were measured weekly (APHA, 1989). During the experimental trail, fish were fed four times a day ad libitum. The unconsumed feed and fecal matter were siphoned once daily in the morning before feeding. Dead fry were removed, noted for tail bite (type I cannibalism) and also monitored for missing ones (type II cannibalism). At the end of the experiment, the length and weight of surviving fry was measured and their count noted.

A total of three samplings were carried out at fortnightly intervals $(15,30$ and 45 days of culture, DOC) to assess the biomass and the quantity of feed was adjusted accordingly. During sampling, total length (L) in $\mathrm{cm}$ and weight (W) in $\mathrm{g}$ of 30 fishes each were measured using a graduated scale and a digital electronic balance. The parameters recorded at the end of each sampling comprised growth (\%), specific growth rate (SGR), feed conversion ratio (FCR), protein efficiency ratio (PER), cannibalism (\%), coefficient of variation $(\mathrm{CV} \%)$, size heterogeneity $(\mathrm{SH}$, weight), survival rate (\%) and condition factor $(\mathrm{K})$. The mathematical relationship between length and weight was calculated at each sampling using the conventional formula, $\mathrm{W}=\mathrm{aL}^{\mathrm{b}}$, by regression after $\log$ transformation (Pauly, 1993).

All the parameters were calculated as follows:

\begin{tabular}{|c|c|}
\hline Weight gain $(\%)$ & $\begin{aligned}= & 100 \times(\text { Average final weight }- \text { Average } \\
& \text { initial weight/Average initial weight })\end{aligned}$ \\
\hline Specific growth rate $\left(\%\right.$ day $\left.^{-1}\right)$ & $\begin{aligned}= & {[(\ln \text { Average final weight }-\ln \text { Average }} \\
& \text { initial weight }) / \text { Time }(\text { days }) \times 100]\end{aligned}$ \\
\hline Feed conversion ratio (FCR) & $\begin{aligned}= & \text { Total feed given (dry weight) }(\mathrm{g}) / \\
& \text { Weight gain (Wet weight })(\mathrm{g})\end{aligned}$ \\
\hline Protein efficiency ratio (PER) & $\begin{aligned}= & \text { Total wet weight gain }(\mathrm{g}) / \text { Crude } \\
& \text { protein fed or intake }(\mathrm{g})\end{aligned}$ \\
\hline Cannibalism(\%) & $\begin{aligned}= & 100 \times\{\text { Initial number of fish }-(\text { Final number } \\
& \text { of fish }+ \text { Number of dead fish } \\
& \text { registered })\} / \text { Initial number of fish }\end{aligned}$ \\
\hline Coefficient of variation (\%) & $\begin{aligned}= & (\text { Standard deviation of individual weight } / \\
& \text { Mean individual weight }) \times 100\end{aligned}$ \\
\hline Size heterogeneity (weight) & $\begin{aligned}= & \text { Final coefficient of variation/Initial } \\
& \text { coefficient of variation }\end{aligned}$ \\
\hline Survival rate (\%) & $\begin{aligned}= & (\text { Final number of fish } x 100) / \text { Initial } \\
& \text { number of fish }\end{aligned}$ \\
\hline
\end{tabular}

Fulton's condition equation (Ricker, 1975; Chow and Sandifer, 1991) was used to find out the condition factor: $\mathrm{K}=\mathrm{W} / \mathrm{L}^{3} \mathrm{X} 100$ where, $\mathrm{K}=$ condition factor, $\mathrm{W}=$ weight of fish $(\mathrm{g})$ and $\mathrm{L}=$ total length $(\mathrm{cm})$. Comparison of all the variables during different DOC was made using one way analysis of variance (ANOVA). Statistical analyses were performed using SPSS for windows (version 20.0) software.

\section{Results and discussion}

In the present experiment, physio-chemical parameters of water such as temperature, salinity, $\mathrm{pH}$, dissolved oxygen, total ammonia and nitrite were in the range of $28-32^{\circ} \mathrm{C}, 25-28 \mathrm{ppt}, 7.4-7.9,5.0-5.5 \mathrm{ppm}$, 0.10-0.15 ppm and 0.02-0.05 ppm, respectively. The body weight of experimental groups at 15 days interval is shown in Fig. 1. Growth parameters, such as growth percentage, SGR, FCR, PER and survival are presented in Table 1.

Effects of TRP supplemented diet on aggression behaviour in fishes is intervened by brain serotonin level which may also control food intake and growth (De Pedro et al., 1998; Hseu et al., 2003; Papoutsoglou et al., 2005a, b). No significant difference $(\mathrm{p}>0.05)$ was observed in SGR among T1, T2, T3, T4 and T5 groups, however weight gain percentage was significantly higher in T3 group. Present finding is similar to the observation made by Jarosław Kro'1 and Zdzisław Zake (2015) in 


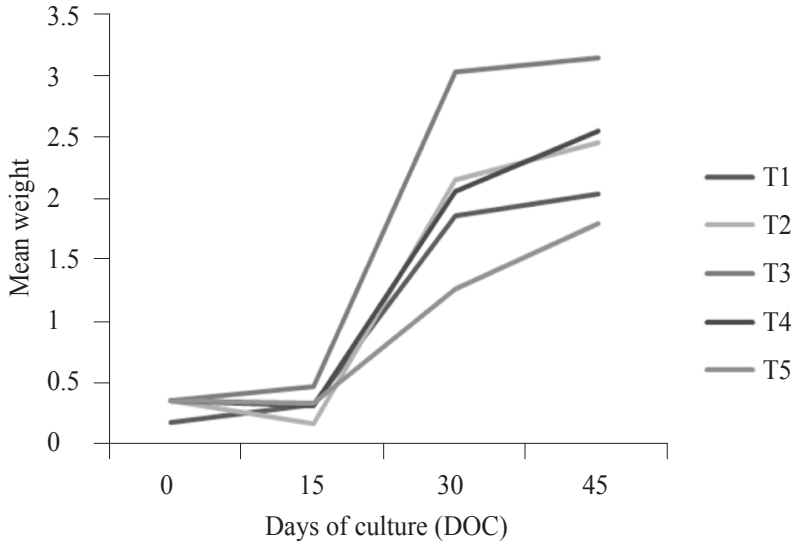

Fig. 1. Mean average body weight of Lates calcarifer fry at 15-day intervals fed with different experimental diets. Mean values are data of three replicates $(n=3) . T 1, T 2$, T3, T4 and T5 indicates $0,0.5,1.0,1.5$ and $2 \%$ TRP supplemented experimental diets respectively and feed intake (Peng and Peter, 1997; Lin et al., 2000). The mean survival rate of the experimental groups varied significantly $(\mathrm{p}<0.01)$. The lowest survival percentage (14 \pm 2.94$)$ was noticed in control group (T1), whereas maximum survival $(39.80 \pm 3.00)$ was observed in T3 group which did not vary significantly from T2, T3 and T5 groups. L-TRP supplementation was found to improve survival rate in $L$. calcarifer due to reduced cannibalism. Similar observation was made by Hseu et al. (2003) in E. coioides. Dietary supplementation of TRP has been shown to reduce aggressive behaviour in several fish species viz., Oncorhynchus mykis, (Winberg et al., 2001); E. coioides (Hseu et al., 2003); G. morhua (Hoglund et al., 2005) and Sander lucioperca (Jarosław Kro'l and Zdzisław Zake, 2015) due to higher level of brain 5-HT. Coefficient of variation (\%), size heterogeneity (\%) and condition factor $(\mathrm{K})$ are shown in Table 1. Cannibalism (\%)

Table 1. Weight gain (\%), Specific growth rate (SGR), Feed conversion ratio (FCR), Protein efficiency ratio (PER), Survival (\%), Coefficient of variation (\%), Size heterogeneity (Weight) and Condition factor (K) of L. calcarifer fry fed with different experimental diets

\begin{tabular}{lllllllll}
\hline Treatments & $\begin{array}{l}\text { Weight gain } \\
(\%)\end{array}$ & SGR & FCR & PER & $\begin{array}{l}\text { Survival } \\
(\%)\end{array}$ & $\begin{array}{l}\text { Coefficient of } \\
\text { variation (\%) }\end{array}$ & $\begin{array}{l}\text { Size } \\
\text { heterogeneity }\end{array}$ & K \\
\hline T1(Control) & $154.6 \pm 5.54$ & $4.80 \pm 0.68$ & $6.14^{\mathrm{a}} \pm 0.81$ & $0.37^{\mathrm{ac}} \pm 0.05$ & $14^{\mathrm{b}} \pm 2.94$ & $91.61^{\mathrm{a}} \pm 18.68$ & $2.05^{\mathrm{a}} \pm 0.42$ & $0.88^{\mathrm{b}} \pm 0.05$ \\
T2 & $167.5 \pm 4.51$ & $5.51 \pm 0.53$ & $4.43^{\mathrm{b}} \pm 0.45$ & $0.46^{\mathrm{bc}} \pm 0.04$ & $38.89^{\mathrm{a}} \pm 1.11$ & $29.52^{\mathrm{b}} \pm 3.70$ & $0.66^{\mathrm{b}} \pm 0.08$ & $1.07^{\mathrm{a}} \pm 0.02$ \\
T3 & $183.8^{\mathrm{a}} \pm 4.18$ & $5.83 \pm 0.50$ & $3.58^{\mathrm{b}} \pm 0.18$ & $0.53^{\mathrm{b}} \pm 0.03$ & $39.80^{\mathrm{a}} \pm 3.00$ & $38.59^{\mathrm{b}} \pm 5.56$ & $0.86^{\mathrm{b}} \pm 0.12$ & $1.15^{\mathrm{a}} \pm 0.04$ \\
T4 & $165.1 \pm 6.64$ & $6.34 \pm 0.61$ & $2.94^{\mathrm{c}} \pm 0.28$ & $0.69^{\mathrm{a}} \pm 0.06$ & $39.78^{\mathrm{a}} \pm 3.66$ & $32.23^{\mathrm{b}} \pm 1.60$ & $1.01^{\mathrm{b}} \pm 0.25$ & $1.89^{\mathrm{a}} \pm 0.07$ \\
T5 & $156.4 \pm 3.23$ & $5.53 \pm 0.50$ & $4.17^{\mathrm{bc}} \pm 0.21$ & $0.45^{\mathrm{abc}} \pm 0.02$ & $33.33^{\mathrm{a}} \pm 2.79$ & $21.50^{\mathrm{b}} \pm 2.70$ & $0.48^{\mathrm{b}} \pm 0.06$ & $0.55^{\mathrm{b}} \pm 0.04$ \\
\hline
\end{tabular}

Values represent Mean \pm SE. Mean values are data of three replicates $(n=3)$ where 30 individuals of each replicate have been pooled for analysis. Same superscripts in each column indicate no significant differences at $\mathrm{p}>0.05$ level. T1, T2, T3, T4 and T5 indicate $0,0.5,1.0,1.5$ and $2 \%$ TRP supplemented experimental diets

pike perch, Sander lucioperca post-fry. They observed that the dietary supplementation of TRP does not affect growth of fish fry. However, Hseu et al. (2003) observed that juvenile grouper, Epinephelus coioides fed with TRP supplemented diet expressed lower growth rates due to increased brain serotonergic activity and decreased aggression and/or appetite. In the present study, we observed a significant reduction in FCR due to TRP supplementation compared to control groups which is similar to the finding of Papoutsoglou et al. (2005 a, b) in European seabass, Dicentrarchus labrax. Reduction in FCR might be due to lower feed intake resulted from increased brain serotonergic activity which is also reported in mammals and birds (Pinchasov et al., 1989; Young, 1996). In goldfish, Carassius auratus, intracerebro ventricular injection of serotonin (5-HT) significantly reduced feed intake (De Pedro et al., 1998). Peng and Peter (1997) reported that 5-HT can directly act on somatotroph cells of the pituitary gland and inhibit growth hormone secretion in goldfish. In fish, growth hormone plays an important role in controlling growth ranged from $15.68 \pm 2.35$ to $37.78 \pm 2.22$ (Fig. 2). Maximum cannibalism (\%) was observed in control group compared to treatment groups and significant reduction in cannibalism was noticed in TRP supplemented groups. In European seabass D. labrax, $37 \%$ of fish were found to be cannibalistic (Katavic et al., 1989) and in Asian seabass $L$. calcarifer maximum of $17.71 \%$ fish were found to be cannibalistic (Sukumaran et al., 2011). Coefficient of variation (\%) ranged from $21.50 \pm 2.70$ to $91.61 \pm 18.68$ which reduced in all TRP supplemented groups. A similar trend was observed for size heterogeneity. Hseu et al. (2003) reported that dietary supplementation of TRP reduces size heterogeneity in juvenile grouper and thereby intensity of cannibalism. They indicated that dietary supplementation of TRP at levels of 0.25 to $1 \%$ of the dry diet, significantly increases brain 5-HT level and reduces cannibalism in grouper juveniles. Condition factor is used to compare the condition, fatness or wellbeing of the fish and can be useful for management of culture systems as it gives indication of favourable or stress factors in the system (Biswas et al., 2011). In 


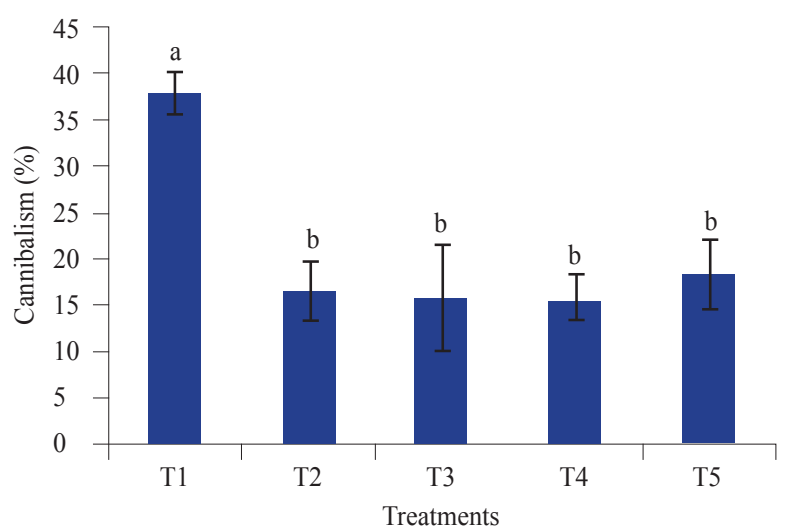

Fig. 2. Effects of dietary tryptophan on cannibalism (\%) of Lates calcarifer fry. Mean values are data of three replicates $(n=3)$. Same letters on bars indicate no significant differences at $\mathrm{p}>0.05$ level. T1, T2, T3, T4 and T5 indicate $0,0.5,1.0,1.5$ and $2 \%$ TRP supplemented experimental diets respectively

the present study, TRP supplementation up to $1.5 \%$ level improved the $\mathrm{K}$ value whereas poor condition was noticed in $2 \%$ TRP supplemented group. Parameters of the lengthweight relationship and coefficient of correlation $\left(\mathrm{R}^{2}\right)$ for different treatments are shown in Table 2.

Lower $\mathrm{R}^{2}$ value in $\mathrm{T} 1, \mathrm{~T} 4$ and $\mathrm{T} 5$ groups revealed that the linearity is less in these groups than the other groups. According to Enin (1994) when the parameter b is equal to 3 , growth is called isometric and when it is less or greater than 3 it is allometric. In the present study, all the treatments showed negative allometry $(b<3)$ type of growth patterns where weight was not symmetrical with length.

In summary, the present results showed that dietary supplementation of tryptophan (TRP) at 0.5 to $2 \%$ reduces cannibalism without affecting the growth performance of seabass fry. Hence, it is recommended to supplement $0.5 \%$ of TRP in diet to reduce cannibalism and improve the survival of seabass fry. However, further study is required to find the effect of higher levels of TRP supplementation.

Table 2. Length-weight relationship, proportionality constant (a), regression coefficient (b) and coefficient of correlation $\left(\mathrm{R}^{2}\right)$ of Lates calcarifer fry fed with different experimental diets

\begin{tabular}{lllll}
\hline Treatments & $\mathrm{a}$ & $\mathrm{b}$ & $\mathrm{R}^{2}$ & $\mathrm{~L}-\mathrm{W}$ relationship \\
\hline T1 (Control) & 0.3897 & 1.4751 & 0.4585 & $\mathrm{~W}=0.3897 \mathrm{~L}^{1.4751}$ \\
T2 & 0.1614 & 2.3688 & 0.7982 & $\mathrm{~W}=0.1614 \mathrm{~L}^{2.3688}$ \\
T3 & 0.0584 & 2.7797 & 0.8014 & $\mathrm{~W}=0.0584 \mathrm{~L}^{2.7797}$ \\
T4 & 1.4805 & 1.3841 & 0.3595 & $\mathrm{~W}=1.4805 \mathrm{~L}^{1.3841}$ \\
T5 & 0.3694 & 0.247 & 0.08 & $\mathrm{~W}=0.3694 \mathrm{~L}^{0.247}$ \\
\hline
\end{tabular}

T1, T2, T3, T4 and T5 indicate 0, 0.5, 1.0, 1.5 and 2\% TRP supplemented experimental diets respectively

\section{Acknowledgements}

The authors are thankful to the Director, ICAR-Central Institute of Brackishwater Aquaculture, Chennai for providing facilities to conduct the experiments.

\section{References}

APHA 1989. Standard methods for the examination of water and wastewater, $17^{\text {th }}$ edn. American Public Health Association, Washington D. C., USA, p. 10-203.

Baras, E. 1998. Bases biologiques du cannibalisme chez les poisons. Cah. Ethol., 18: 53-98.

Baras, E. 1999. Sibling cannibalism among juveniles under controlled conditions, I. Cannibalistic behaviour, prey selection and prey size selectivity. J. Fish Biol., 54: 82-105.

Baras, E. 2013. Cannibalism in fish fry: What have we learned? In: Qin, J. G. (Ed.), Larval fish aquaculture. Nova Science Publishers, New York, USA, 31 pp.

Baras, E. and Jobling, M. 2002. Dynamics of intracohort cannibalism in cultured fishes. Aquac. Res., 33: 461-479.

Baras, E., Kestemont, P. and Melard, C. 2003. Effect of stocking density on the dynamics of cannibalism in sibling fry of Perca fluviatilis under controlled conditions. Aquaculture, 219(1-4): 241-255.

Biswas, G., Thirunavukkarasu, A. R., Sundaray, J. K. and Kailasam, M. 2011. Culture of Asian Seabass Lates calcarifer (Bloch) in brackishwater tide-fed ponds: growth and condition factor based on length and weight under two feeding systems. Indian J. Fish., 58(2): 53-57.

Chow, S. and Sandifer, P. A. 1991. Differences in growth, morphometric traits and male sexual maturity among Pacific white shrimp Peneaus vannamei, from different commercial hatcheries. Aquaculture, 92: 165-179.

Cuff, W. R. 1980. Behavioural aspects of cannibalism in larval walleye, Stizostedion vitreum. Can. J. Zool., 58(8): 1504-1507.

De Pedro, N., Pinillos, M. L., Valenciano, A. I., Alonso-Bedate, M. and Delgardo, M. J. 1998. Inhibitory effects of serotonin on feeding behaviour in goldfish: involvement of CRF. Peptides, 19: 505-511.

Enin, U. 1994. Length-weight parameters and condition factor of two West African prawns. Rev. d'Hydrobiol. Trop., 27: 121-127.

Greenwood, P. H. 1976. A review of the family centropomidae (Pisces: Perciformes). Bulletin of the British museum (Natural History). Zoology, 29: 1-81.

Grey, D. L. 1987. An overview of Lates calcarifer in Australia and Asia. In: Copland J. W. and Grey D. L. (Eds.), Management of wild and cultured seabass Barramundi (Lates calcarifer). Proceedings of international workshop, Darwin, 24-30 September, 1986. p. 15-21. 
Hecht, T. and Appelbaum, S. 1988. Observations on intraspecific aggression and sibling cannibalism by larva and juvenile Clarias gariepinus (Clariidae: Pisces) under controlled conditions. J. Zool. (London), 214: 21- 44.

Hecht, T. and Pienaar, A. G. 1993. A review of cannibalism and its implications in fish larviculture. J. World Aquac. Soc., 24: $246-261$.

Hoglund, E., Bakke, M. J., Overli, O., Winberg, S. and Nilsson, G. E. 2005. Suppression of aggressive behaviour in juvenile Atlantic cod (Gadus morhua) by L-tryptophan supplementation. Aquaculture, 249(1-4): 525-531.

Hseu, J. R., Lu, F. I., Su, H. M., Wang, L. S., Tsai, C. L. and Hwang, P. P. 2003. Effects of exogenous tryptophan on cannibalism, survival and growth in juvenile grouper, Epinephelus coioides. Aquaculture, 218: 251-263.

Johnston, W. L., Atkinson, J. L., Hilton, J. W. and Were, K. E. 1990. Effect of dietary tryptophan on plasma and brain tryptophan, brain serotonin and brain 5-hydroxyindoleacetic acid in rainbow trout. J. Nutr. Bio., 1(1): 49-54.

Katavic, I., Jug-Dujakovic, J. and Glamuzina, B. 1989. Cannibalism as a factor affecting the survival of intensively cultured seabass (Dicentrarchus labrax) fingerlings. Aquaculture, 77(2-3): 135-143.

Jarosław, Kro'L. and Zdzisław Zake, S. 2015. Effect of dietary L-tryptophan on cannibalism, survival and growth in pikeperch Sander lucioperca (L.) post-fry. Aquac. Int., DOI 10.1007/s10499-015-9936-1.

Lepage, O., Tottmar, O. and Winberg, S. 2002. Elevated dietary intake of L-tryptophan counteracts the stress-induced elevation of plasma cortisol in rainbow trout (Oncorhynchus mykiss). J. Expt. Biol., 205(23): 3679-3687.

Lin, X., Volkoff, H., Narnaware, Y., Bernier, N. J., Peyen, P. and Peter, R. E. 2000. Brain regulation of feeding behavior and food intake in fish. Comp. Biochem. Physiol., A 126: 415-424.

Loadman, N. L., Moodie, G. E. E. and Mathias, J. A. 1986. Significance of cannibalism in larval walleye (Stizostedion vitreum). Can. J. Fish. Aquat. Sci., 43(3): 613-618.

Papoutsoglou, S. E., Karakatsouli, N. and Chiras, G. 2005a. Dietary L-tryptophan and tank colour effects on growth performance of rainbow trout (Oncorhynchus mykiss) juveniles reared in a recirculating water system. Aquac. Engg., 32(2): 277-284.

Papoutsoglou, S. E., Karakatsouli, N. and Koustas, P. 2005 b. Effects of dietary L-tryptophan and lighting conditions on growth performance of European seabass (Dicentrarchus labrax) juveniles reared in a recirculating water system. J. Appl. Ichthyol., 21(6): 520-524.

Pauly, D. 1993. Editorial, Fish byte. NAGA, ICLARM Q., p. 16-26.

Peng, C. and Peter, R. E. 1997. Neuroendocrine regulation of growth hormone secretion and growth in fish. Zool. Stud., 36: 79-89.

Pinchasov, Y., Fancher, B. I., Burke, W. H. and Jensen, L. S. 1989. Glycolic acid and tryptophan effects on feed intake and hypothalamic indolamines in chicks. Physiol. Behav., 45: $585-589$.

Ricker, W. E. 1975. Computation and interpretation of biological statistics of fish populations. Fish. Res. Board of Canada Bull., 191: 203-233.

Sukumaran, K., Arasu, A. R.T., Kailasam, M., Sundaray, J. K., Subbura, R. and Thiagrajan, G. 2011. Effect of stocking density on size heterogeneity and sibling cannibalism in Asian seabass Lates calcarifer (Bloch, 1790) fry. Indian J. Fish., 58(3): 145-147.

Thirunavukkarasu, A. R., Kailasam, M., Kishore Chandra, P., Shiranee, P., Mathew Abraham, Charles, A. V. K. and Subburaj, R. 2001. Captive broodstock development and breeding of seabass Lates calcarifer (Bloch) in India. In: Menon, N. G. and Pillai, P. P. (Eds.), Perspectives in mariculture. The Marine Biological Association of India, Cochin, p. 111-124.

Winberg S., Overil, O. and Lepage, O. 2001. Suppression of aggression in rainbow trout (Oncorhynchus mykiss) by dietary L-tryptophan. J. Exp. Biol., 204(22): 3867-3876.

Winberg, S., Overil, O. and Lepage, O. 2001. Suppression of aggression in rainbow trout (Oncorhynchus mykiss) by dietary L-tryptophan. J. Exp. Biol., 204(22): 3867-3876.

Young, S. N. 1996. Behavioral effects of dietary neurotransmitter precursor: basic and clinical aspects. Neurosci. Biobehav. Rev., 20: 313-323. 